This article has been published in the Journal of Transport \& Health. This is the final version submitted for publication. The full reference is:

Mackett R L (2014) The health implications of inequalities in travel, Journal of Transport and Health, 1, 202-209, doi:10.1016/j.jth.2014.07.002, available from: http://dx.doi.org/10.1016/j.jth.2014.07.002. 


\title{
The health implications of inequalities in travel
}

\author{
R L Mackett
}

Centre for Transport Studies, University College London, Gower Street, London, WC1E 6BT, Great Britain.

E-mail: r.mackett@ucl.ac.uk

Telephone: +442076791554

\begin{abstract}
The purpose of this paper is to examine whether some groups in society have poorer travel opportunities or are affected adversely by transport more than others with consequent implications for their health. The following potential inequalities in access to travel are considered: income, ethnicity, gender, rurality and disability. The impacts of two externalities of the transport system are considered: casualty rates and atmospheric emissions. Access to a car is found to be a key factor. Generally, the inequalities are decreasing over time as those with lower incomes increase their car ownership towards the levels of those with higher incomes.
\end{abstract}

\section{Highlights}

- Large differences exist in the volumes of travel by various groups in society.

- These differences are decreasing over time.

- There are large differences in access between urban and rural areas.

- Cultural factors contribute to differences in access.

- Casualty rates and vehicle emissions impact more on the poor than the rich.

\section{Key words}

inequalities; income; gender; ethnicity; rural; casualties. 


\section{Introduction}

Travel has a number of links with health: for example, walking and cycling ('active travel') provide exercise directly. Travel is the means to access shops selling healthy food and health care facilities and to reach recreational facilities offering the opportunity to exercise, both indoors and outdoors. The limited availability of time in the day means that faster modes of travel offer access to more opportunities and faster modes, such as cars and trains, tend to be more expensive than walking, cycling and bus. This means that those with higher incomes are able to reach more locations to purchase healthy food, attend health care facilities and obtain exercise. Because travel often requires monetary expenditure and the opportunities that are required for a healthy lifestyle are distributed unevenly over space, there are bound to be differences in the resources required to access them. Jobs, schools and shops tend to cluster in urban areas, so those living in rural areas tend to live further from many of these opportunities than those in urban areas, so those living in rural areas may have more difficulty leading healthy lifestyles. Transport can have an adverse effect on health, for example, through casualties from road crashes and atmospheric emissions.

The purpose of this paper is to examine whether particular groups in society in Britain such as those with low incomes or those living in rural areas appear to have significantly poorer travel opportunities or are affected adversely by transport more than others with consequent implications for their health. This is a vast subject and the objective of this paper is to establish whether such inequalities exist using the literature and secondary data including the UK National Travel Survey, the UK Family Resources Survey and the Statistical Digest of Rural England, so that others can then research into specific aspects of the topic.

\section{Income inequalities}

A key link between income and travel is the amount of money spent on travel. In Britain, the percentage of total expenditure on travel increases with income, as do the purchase of vehicles such as cars and the operation of personal transport (Office for National Statistics, 2012a). Expenditure on rail and Tube fares also increases with income because rail travel is relatively expensive and is often associated with commuting and business travel particularly in South East England where incomes tend to be higher. In contrast, the percentage of total expenditure spent on bus and coach travel decreases with income, reflecting its characteristic as the cheapest form of public transport.

The link between income and car ownership is illustrated in Table 1 which shows how car ownership increases with income. Between 2002 and 2012 the overall percentage of households with access to a car decreased from $78 \%$ to $75 \%$, but the percentage with two or more cars increased from $25 \%$ to $31 \%$. The percentage of households owning one or more cars has increased for the two lower income groups, but decreased for the upper three income groups. The number of households owning two or more cars has increased for all the income groups, but more for the lower income groups. This suggests that the differences in car ownership levels between income groups are decreasing. 
Table 1. Household car availability by real household income quintile in Great Britain, 2002 and 2012

\begin{tabular}{lrrrrrr}
\hline \multicolumn{7}{c}{$\mathbf{c}$ Percentage of households } \\
\hline & No & One or & Two or & No & One or & Two or \\
& car & more car & more cars & car & more car & more cars \\
& $(\%)$ & $(\%)$ & $(\%)$ & $(\%)$ & $(\%)$ & $(\%)$ \\
Lowest real income & 59 & 41 & 6 & 48 & 52 & 11 \\
Second level & 42 & 58 & 11 & 35 & 65 & 19 \\
Third level & 18 & 82 & 25 & 20 & 80 & 32 \\
Fourth level & 12 & 88 & 36 & 13 & 87 & 43 \\
Highest real income & 8 & 92 & 48 & 11 & 89 & 50 \\
\hline All households & 22 & 78 & 25 & 25 & 75 & 31
\end{tabular}

Source: Department for Transport (2013a)

Tables 2 shows how the total numbers of trips by the various modes per head per year varies by income group in 2002 and 2012. Overall, there has been a decrease in the number of trips per head by about $9 \%$, with decreases in the number of trips by walking, car and bus, and an increase in the number by rail. There is clear difference in the use of the various modes with income although the ranking of the modes for each income group are similar. Car is used for the most trips even by the lowest income group, but they make just over half the number made by the top group. Low income people make over three times as many bus trips as the highest group. Rail has the largest differential with the top income group making nearly four times as many as the lowest income group. Low income people also walk more than the rich, but the differential is much less, with the highest income group walking about $30 \%$ fewer trips than the lowest group. The bicycle is the mode with the smallest variation across the income groups, but in 2012 tends to increase slightly with income, which is not necessarily what would be expected. In 2002 there was less difference in cycle use across the income bands, suggesting that those with higher incomes are favouring cycling more than in the recent past, possibly for health or sustainability reasons, or possibly to avoid delays on public transport and in the car.

Table 2. Number of trips per head per year by mode, by household income quintile in Great Britain, 2012

\begin{tabular}{lrrrrrrrrrrrr}
\hline & \multicolumn{4}{c}{$\mathbf{2 0 0 2}$} & \multicolumn{1}{c}{$\mathbf{2 0 1 2}$} \\
\hline & Walk & Bicycle & Car & Bus & Rail & Total & Walk & Bicycle & Car & Bus & Rail & Total \\
\hline $\begin{array}{l}\text { Lowest real } \\
\text { income }\end{array}$ & 294 & 14 & 399 & 101 & 13 & 848 & 260 & 15 & 400 & 101 & 15 & 819 \\
$\begin{array}{l}\text { Second } \\
\text { level }\end{array}$ & 282 & 15 & 580 & 79 & 11 & 996 & 236 & 14 & 520 & 73 & 15 & 884 \\
$\begin{array}{l}\text { Third level } \\
\text { Fourth level }\end{array}$ & 232 & 19 & 721 & 60 & 17 & 1074 & 195 & 14 & 658 & 60 & 19 & 967 \\
$\begin{array}{l}\text { Highest real } \\
\text { income }\end{array}$ & 203 & 16 & 834 & 46 & 24 & 1149 & 189 & 18 & 748 & 41 & 32 & 1047 \\
\hline All & 204 & 17 & 857 & 32 & 50 & 1187 & 182 & 19 & 739 & 31 & 56 & 1052 \\
& 244 & 16 & 674 & 65 & 22 & 1047 & 212 & 16 & 614 & 61 & 27 & 954 \\
\hline
\end{tabular}

Source: Department for Transport (2013a)

Note: 'Bus' includes coach; 'other' modes are included in the 'Total' column.

The distance travelled by the modes (Table 3 ) is relevant to health. Walking and cycling provide physical activity which contributes to health while the car offers access to a wider range of 
health facilities and opportunities for physical activity. It can be seen that the distance walked each year tends to decrease with income apart from the top group in 2012; over time, the amount of walking has decreased for all income groups except the highest. Cycling tends to increase with income and has increased over time for all income groups, especially the highest income group. This means that, in 2012, those with the highest incomes not only travel furthest by car they also travel furthest using active travel (walking and cycling combined). This is in contrast with ten years earlier when this group had the lowest combined total for walking and cycling.

Table 3. Distance in kilometres per head per year by mode, by real household income quintile in Great Britain, 2012

\begin{tabular}{|c|c|c|c|c|c|c|c|c|c|c|c|c|}
\hline & \multicolumn{5}{|c|}{2002} & \multicolumn{7}{|c|}{2012} \\
\hline & Walk & Bicycle & Car & Bus & Rail & Total & Walk & Bicycle & Car & Bus & Rail & Total \\
\hline $\begin{array}{l}\text { Lowest real } \\
\text { income }\end{array}$ & 352 & 29 & 4,211 & 792 & 464 & 6,669 & 328 & 66 & 4,330 & 835 & 508 & 6,382 \\
\hline $\begin{array}{l}\text { Second } \\
\text { level }\end{array}$ & 333 & 32 & 5,990 & 613 & 357 & 8,248 & 294 & 56 & 5,826 & 706 & 512 & 7,768 \\
\hline Third level & 286 & 61 & 8,544 & 496 & 542 & 11,165 & 269 & 78 & 8,374 & 602 & 707 & 10,349 \\
\hline Fourth level & 283 & 70 & 11,014 & 466 & 786 & 13,725 & 267 & 91 & 10,366 & 414 & 1026 & 12,526 \\
\hline $\begin{array}{l}\text { Highest real } \\
\text { income }\end{array}$ & 270 & 67 & 14,750 & 317 & 2003 & 18,370 & 286 & 131 & 12,867 & 389 & 2310 & 16,622 \\
\hline All & 302 & 53 & 8992 & 544 & 790 & 11418 & 290 & 85 & 8342 & 589 & 1002 & 10706 \\
\hline
\end{tabular}

Source: Department for Transport (2013a)

Note: 'Bus' includes coach; 'other' modes are included in the 'Total' column.

An important aspect of obtaining access to good quality travel is being able to access information and book travel when appropriate from home. Until fairly recently this meant using the telephone. Availability of home and mobile phones increases with income (Office for National Statistics, 2012a). At the higher income levels, access to a telephone is close to $100 \%$ whereas only $66 \%$ of the lowest income decile group have a home telephone and $75 \%$ a mobile phone. Interestingly this group is almost the only one to have more access to mobile phones than to home phones, perhaps reflecting the fact that it is possible to purchase a basic mobile phone on a pay-as-you-go tariff very cheaply. Nowadays, travel information is increasingly being made available over the internet. Here there is a larger difference between those with low and those with high incomes with only $41 \%$ of those in each of the two lowest income decile groups with internet access compared with $99 \%$ of those in the top group. It is clear that many of those on very low incomes do not have access to travel information from home. This means that they are unlikely to find out about the most cost-effective and efficient ways to travel, and so may be spending more money and time travelling than those with higher incomes who are more likely to be able to access good quality information.

All forms of transport require some form of public investment, in terms of the provision of infrastructure and subsidy. Horten and Reed (2010) have examined Government spending by income group and found that expenditure on transport is biased towards higher income groups, unlike some other forms of public expenditure such as health, education and housing. This is probably because, as shown above, those with higher incomes travel more, particularly by car and rail, both of which receive large volumes of public expenditure.

\section{Gender}

Women tend to have different employment patterns, different time use patterns, and fewer financial resources than men (Hamilton et al., 2005). They are more likely to be travelling encumbered by children or shopping and have concerns about personal security. These influence the times and ways in which they travel. Inadequate consideration of women's travel 
can result directly in social exclusion, but it can also have other health consequences such as an inability to access shops selling healthy food, or difficulties reaching hospital care, particularly when pregnant. As Table 4 shows, women make more trips than men. They make more walking, car passenger and bus trips than men but fewer bicycle, car driver and rail trips. Since 2002, they have increased their number of car driver trips, unlike men, but they have decreased the number of bus trips they make: some of these have been transferred to car driver trips. In 2002 only $61 \%$ of women held a full car driving licence, whereas $80 \%$ of men did (Department for Transport, 2013a). The proportion of women who can drive increased to $66 \%$ by 2012 whereas the proportion of men has stayed level at about $80 \%$. It may be that as the state of the U.K. economy improves, the proportion of women who can drive may approach that of men.

Table 4. Trips per year per head by gender and mode: Great Britain, 2002 and 2012

\begin{tabular}{lrrrrrr}
\hline & \multicolumn{3}{c}{$\mathbf{2 0 0 2}$} & & \multicolumn{2}{c}{$\mathbf{2 0 1 2}$} \\
\hline & Male & Female & $\begin{array}{l}\text { Ratio of } \\
\text { male to } \\
\text { female }\end{array}$ & Male & Female & $\begin{array}{l}\text { Ratio of } \\
\text { male to } \\
\text { female }\end{array}$ \\
\hline Walk & 225 & 260 & 0.87 & 202 & 223 & 0.91 \\
Bicycle & 21 & 9 & 2.33 & 23 & 9 & 2.56 \\
Car / van driver & 489 & 355 & 1.38 & 438 & 366 & 1.20 \\
Car / van passenger & 176 & 280 & 0.63 & 163 & 261 & 0.62 \\
Bus & 46 & 69 & 0.67 & 53 & 69 & 0.77 \\
Rail & 27 & 17 & 1.58 & 31 & 24 & 1.29 \\
\hline All modes & 1005 & 1011 & 0.99 & 935 & 972 & 0.96 \\
\hline
\end{tabular}

Source: Department for Transport (2013a)

Note: 'Bus' includes coach; 'All modes' includes 'other' modes.

The distances travelled by members of each gender are shown in Table 5. Overall, men travel further than women despite making fewer trips but the difference is decreasing over time. Car is the dominant mode. The distance driven by car has gone up only slightly since 2002 for females, but it has declined significantly for men. Women travelled further as car drivers than car passengers in 2012, whereas in 2002 they travelled further as passengers than as drivers. Even though they made more walking trips than men, they did not walk quite as far as men in 2012. Because they cycled less far than men in both 2002 and 2012 the total distance travelled by active modes was less by women than by men. Summing up, in 2012, men travelled further than women by all modes except bus, but the differences for car drivers and rail are decreasing over time. The increase in bus use by men may be partly due to the availability of free bus travel for all those over the age of 62 (Mackett, 2014). 
Table 5. Distance in kilometres per year per head by gender and mode: Great Britain, 2002 and 2012

\begin{tabular}{lrrrrrr}
\hline & & $\mathbf{2 0 0 2}$ & & & $\mathbf{2 0 1 2}$ \\
\hline & Male & Female & $\begin{array}{l}\text { Ratio of } \\
\text { male to } \\
\text { female }\end{array}$ & Male & Female & $\begin{array}{l}\text { Ratio of } \\
\text { male to } \\
\text { female }\end{array}$ \\
\hline Walk & 309 & 322 & 0.96 & 290 & 288 & 1.01 \\
Bicycle & 90 & 27 & 3.33 & 138 & 32 & 4.31 \\
Car / van driver & 8,046 & 3,765 & 2.14 & 6,866 & 3,960 & 1.73 \\
Car / van passenger & 2,566 & 4,163 & 0.62 & 2,230 & 3,656 & 0.61 \\
Bus & 464 & 621 & 0.75 & 539 & 637 & 0.85 \\
Rail & 1012 & 576 & 1.76 & 1171 & 840 & 1.39 \\
\hline All modes & 13,045 & 9,861 & 1.32 & 11,696 & 9,749 & 1.30 \\
\hline Soure
\end{tabular}

Source: Department for Transport (2013a)

Note: 'Bus' includes coach; 'All modes' includes 'other' modes.

A key factor underlying the differences in trip patterns by men and women is the different set of purposes for which they travelled (Department for Transport, 2013a). The trip purposes for which women make more trips than men are shopping, personal business and education escort, that is taking children to school, and other escort, which means taking children to places other than school and taking adults to places such as hospitals. They make fewer commuting, business and education trips than men. Women make more leisure trips than men, particularly meeting friends, whereas men make more trips to sport and entertainment. To some extent these represent different roles that men and women are playing in family life.

It can be argued that women's time is under greater pressure than men's (Hamilton, 2001). Pazy et al. (1996) suggested that this results in women emphasising commute time over distance when choosing employment. Women without a strong career orientation have been found to be very sensitive to travel time when they were responsible for pre-school age children, a phenomenon which was even more marked when the women were dependent on public transport (Pazy et al., 1996)

Women are more likely than men to be lone parents. The relationship between lone motherhood and poverty is well established, yet the burdens of transport costs and dependence on public transport are likely to be higher: single mothers make more trips than married mothers (Rosenbloom and Burns, 1994) are five times more likely to use a taxi and 1.5 times more likely to use a bus (Reid-Howie Associates, 2000). It was found that lone parents were twice as likely to be constrained by the cost of travel, and three times as likely to feel limited by lack of facilities.

Because women's journeys, including those to work, tend to be shorter than men's, women are a potential target audience for initiatives to increase cycling to work, as a higher proportion commute less than the three mile distance that the British Medical Association (1992) has suggested the majority of the population could cycle. However, women are twice as likely as men to fear for their safety whilst cycling (Oja et al, 1998) and are more likely to organise their day around complex trip chains (work-school-shopping) which are less conducive to cycling (Dickinson et al, 2003). This contributes to a gender gap in cycling. Female commuter cyclists are more likely to prefer using off-road paths. This phenomenon can be used by designers to increase participation in cycling (Garrard et al, 2008). 
Much of the transport system has been designed to facilitate journeys to work and long journeys, rather than to journeys for child minding or shopping. This can be seen in the radial layout of most cities' public transport systems, where the journey to work is catered for by rapid metro-type transit, whereas journeys to schools and shops are catered for bus services which can be unreliable and infrequent, or non-existent.

Individual vehicle designs also traditionally pay little attention to the needs of women. There has been increased introduction of low floor buses in Britain which are useful to parents travelling with young children who are usually women. Car designs require women, who tend to be shorter than men, to sit closer to the steering wheel than men in order to reach foot pedals, but airbag designs do not reflect this (Reid-Howie Associates, 2000). There is evidence that women are $50 \%$ more likely to be injured in car collisions than men (Spain, 1996).

\section{Ethnicity}

There are differences in travel patterns between ethnic groups, as shown in Table 6, with white people making the largest number of trips at 998 each year whereas those in the 'Other ethnic group' group only make 773 which is over $20 \%$ fewer and lower than the number made by the lowest income quintile according to the National Travel Survey (Department for Transport, 2013a). Whilst income is, almost certainly, a factor, there may also be cultural issues, with members of some groups staying at home more of the time than those in other groups. As discussed above, a key factor in trip making is the availability of a car. White people have the highest car access followed by members of the Asian/Asian British group. Interestingly the Asian/Asian British group make fewer trips per head than two other groups, suggesting that factors in addition to car availability play a part in influencing the number of trips made.

Table 6. Travel by ethnic group in Great Britain, 2012

\begin{tabular}{lcc}
\hline Ethnic group & $\begin{array}{c}\text { Number of trips } \\
\text { per year by } \\
\text { adults }\end{array}$ & $\begin{array}{c}\text { \% of adults in a } \\
\text { household with a car } \\
\text { or van }\end{array}$ \\
\hline White & 998 & 81 \\
Mixed / Multiple ethnic groups & 965 & 67 \\
Black / African / Caribbean / Black British & 839 & 59 \\
Asian / Asian British & 815 & 71 \\
Other ethnic group & 773 & 59 \\
\hline All ethnic groups & 979 & 80 \\
\hline
\end{tabular}

Source: Department for Transport (2013a)

\section{Rurality}

Rural areas tend to be less dense than urban areas, so that destinations are spread more widely, which means that residents have, in general, to travel further to reach opportunities. It also means that bus routes tend to be longer, serving fewer potential passengers per route kilometre, which means that costs are higher and revenues lower. This means that there are relatively few bus routes in rural areas. Table 7 shows the average minimum time to reach various key services by three different modes: a combination of public transport and walking, cycle and car. In all cases the journey by public transport and walking takes longer in rural areas than urban areas, typically about twice as long. There is, generally, greater variation between the time taken in rural and urban areas for cycling. For primary school it is the same at five minutes, but in all other cases it takes longer in rural areas, with the biggest proportional difference being for higher education and town centres which take over three times as long to reach from rural areas as urban areas. The differences by car are much smaller than for the 
other modes, with hospital and town centre having the largest differences. This suggests that having access to a car can largely overcome the poorer access from rural areas.

Table 7. Average minimum travel time to reach the nearest key services by mode of travel in rural and urban areas in England, 2011

\begin{tabular}{|c|c|c|c|c|c|c|c|c|c|}
\hline & & Employment & $\begin{array}{c}\text { Primary } \\
\text { school }\end{array}$ & $\begin{array}{c}\text { Secondary } \\
\text { school }\end{array}$ & $\begin{array}{c}\text { Further } \\
\text { education }\end{array}$ & GP & Hospital & $\begin{array}{l}\text { Food } \\
\text { store }\end{array}$ & $\begin{array}{c}\text { Town } \\
\text { centres }\end{array}$ \\
\hline \multirow{2}{*}{$\begin{array}{l}\text { Public } \\
\text { Transport } \\
\text { / Walking }\end{array}$} & Urban & 9 & 8 & 12 & 14 & 9 & 26 & 7 & $\overline{14}$ \\
\hline & Rural & 16 & 12 & 25 & 28 & 15 & 46 & 14 & 29 \\
\hline \multirow[t]{2}{*}{ Cycle } & Urban & 5 & 5 & 6 & 7 & 5 & 16 & 5 & 8 \\
\hline & Rural & 12 & 5 & 17 & 24 & 10 & 43 & 10 & 26 \\
\hline \multirow[t]{2}{*}{ Car } & Urban & 5 & 5 & 5 & 6 & 5 & 8 & 5 & 6 \\
\hline & Rural & 6 & 5 & 7 & 9 & 6 & 13 & 6 & 10 \\
\hline
\end{tabular}

Source: Department for Transport (2013b)

The differences for public transport between urban and rural areas partly reflect differences in the availability of buses, expressed as the percentage of households whose nearest bus stop is within 13 minutes walk and has a service at least once an hour (Department for Environment, Food \& Rural Affairs, 2013). Over 90\% of those living in an urban area in 2011 met these criteria. Over $80 \%$ of those living in rural towns and fringes had access to a bus service in 2009 , whereas fewer than half of those living in rural villages and hamlets did. In all three types of area access was better in 2009 than in 2002, but it seemed to decrease slightly from 2008 to 2009 in the rural areas, possibly due to economic recession.

This has implications for the total distance travelled by each mode, as shown in Table 8. Those living in rural villages and hamlets travel the furthest by car and least distance by walking, bus, rail or Underground and walking. People in urban areas walk over 50\% further each year than those in the very rural areas and over $25 \%$ more than those in rural towns and fringes. Conversely those in the very rural areas are driving nearly $80 \%$ further than those in urban areas. This is despite the fact that fuel for cars is more expensive in rural areas than urban areas by nearly $2 p$ a litre (Department for Environment, Food \& Rural Affairs, 2012). This all has implications for expenditure (Office for National Statistics, 2012a). Total expenditure each week is higher in rural areas than in urban areas with the largest contributor to this difference being expenditure on transport which is over $30 \%$ higher in rural areas.

Table 8. Distance in kilometres per person per year by main mode, 2006/09

\begin{tabular}{lrrrrrr}
\hline & Walk & Car & $\begin{array}{r}\text { Local } \\
\text { bus }\end{array}$ & $\begin{array}{r}\text { Rail or } \\
\text { Underground }\end{array}$ & Other & Total \\
\hline Urban & 333 & 7842 & 498 & 958 & 579 & 10210 \\
Rural town and fringe & 266 & 12074 & 381 & 878 & 647 & 14243 \\
Rural village and hamlet & 205 & 14041 & 286 & 870 & 702 & 16107 \\
\hline England & 315 & 8808 & 467 & 944 & 595 & 11131 \\
\hline
\end{tabular}

Source: Department for Environment, Food \& Rural Affairs (2013)

The differences in travel patterns between urban and rural areas mean that those in rural areas make more trips, travel further and spend more time travelling than those in urban areas. Coupled with the higher cost of vehicle fuel and the poorer availability of buses in rural, there are clear inequalities in transport provision between rural and urban areas. According to Farringdon and Farringdon (2006), it has frequently been a key assumption of rural planners that those choosing to live in rural areas make the decision in full knowledge that accessibility will be more 
difficult and they must compensate accordingly, usually by car ownership. This assumption fails to consider those for whom living in an inaccessible location was not a choice. This may include those who are tied to a rural livelihood, elderly people and others unable to move away from rural areas, people who become disabled in such a way as to prevent driving, and children not yet old enough to drive. In addition, there are those who have chosen a rural lifestyle for reasons of health, the environment, or cost but would inherently prefer not to be dependent on the car.

\section{Disability}

Transport difficulties are increased in the presence of personal disability. Eleven per cent of the general population has mobility difficulties, defined as anybody who has a disability or long standing illness or condition that makes it difficult either to go out on foot or to use local buses (Department of Transport, 2013a). As Table 9 shows, adults of all ages with mobility difficulties make many fewer trips each year than the rest of the population. In fact, people of all ages with a mobility difficulty, on average, make fewer trips than people aged 70 or over without a mobility difficulty.

Table 9. Trips per person per year by age and mobility status: Great Britain, 2012

\begin{tabular}{lrrrrr}
\hline Mobility status & All aged $\mathbf{1 6 +}$ & $\mathbf{1 6 - 4 9}$ & $\mathbf{5 0 - 5 9}$ & $\mathbf{6 0 - 6 9}$ & $\mathbf{7 0 +}$ \\
\hline With a mobility difficulty & 634 & 725 & 735 & 748 & 517 \\
No mobility difficulty & 1,021 & 1,024 & 1,088 & 1,036 & 871 \\
\hline All & 976 & 1,013 & 1,050 & 986 & 733 \\
\hline Source: Department for Transport (2013a) & & & &
\end{tabular}

Table 10 shows the percentage of people with a long-standing, illness, disability or impairment which causes substantial difficulty with day-to-day activities. The term 'substantial' is subjective. The activities include travel, but some people may be able to travel, but have other difficulties. The table shows that, as well as the $11 \%$ with mobility difficulties, $10 \%$ have difficulty lifting and carrying which may have an impact on shopping trips. Manual dexterity, which affects $4 \%$, could make using coin machines for buying tickets and paying for parking awkward. Similarly, physical co-ordination may hinder paying for tickets or accessing vehicles. Memory/concentration/learning and communication difficulties may make wayfinding and interaction with others during the course of a journey more challenging. Continence issues affect $3 \%$ of the population which may mean that they cannot make trips for fear of not being able to reach a toilet when required. Failure to recognise danger may cause problems when crossing the road for example. It is noticeable that many of these issues increase significantly with age, particularly the physical disabilities.

Table 10. Prevalence of disability by age and impairment type (\% of age group)

\begin{tabular}{lccc}
\hline Impairment type & Working age adults & $\begin{array}{c}\text { State pension age } \\
\text { adults }\end{array}$ & All adults \\
\hline Mobility & 6 & 29 & 11 \\
Lifting, carrying & 6 & 27 & 10 \\
Manual dexterity & 3 & 12 & 4 \\
Physical co-ordination & 2 & 11 & 4 \\
Memory/concentration/learning & 3 & 7 & 4 \\
Communication & 2 & 8 & 3 \\
Continence & 1 & 7 & 3 \\
Recognising when in danger & 1 & 2 & 1 \\
Other & 5 & 11 & 6 \\
\hline
\end{tabular}

Source: Department for Work and Pensions (2012, undated). 
There are 1.2 million wheelchair users in the UK (English Federation of Disability Sport, 2013). There are also many people, predominantly older people, who use mobility scooters to move about locally even though they are able to walk short distances. There are about 360,000 registered blind and partially sighted people in the UK (RNIB, 2013). Almost two million people in the UK are living with sight loss. It is predicted that by 2020 the number of people with sight loss will rise to over 2,250,000, and double to nearly four million by 2050 . More than ten million people have hearing loss (NHS Choices, 2013). There are around one million people with a cognitive impairment and this figure is predicted to rise significantly with the ageing population over the coming years due to increasing numbers of people with strokes or dementia (Foundation for People with Learning Disabilities, 2013). The number of older people in the population is increasing significantly and, as Table $11 \underline{0}$ indicates, many of them have impairments which make travel difficult-(Office for National Statistics, 2012b).

This means that there will be a very substantial number of people for whom mobility may be a problem and whose independence in daily living is likely to be severely affected if they are unable to travel. Restricted mobility may also occur on a temporary or intermittent basis when people are travelling with children, buggies, or luggage or shopping. Transport solutions aimed at those with disabilities will also improve mobility for these individuals.

\section{Inequalities in casualty rates}

People in disadvantaged groups also suffer most from the effects of other people's travel by private motor vehicles. Rates of road traffic injuries show steep social class gradients with the rates increasing with increasing deprivation for most types of road user, especially pedestrians, particularly child pedestrians (Department for Transport, 2008). Children from lower socioeconomic households spend more time walking or playing near roads than their more affluent peers (Vaganay et al., 2003). In the early 2000s, children from the lowest social class were five times as likely to die as pedestrians from road injuries than children from the highest (Department for Transport, 2003). Analysis of child road traffic casualties from 2004 to 2008 found a marked social gradient. Injury rates varied from one child in 206 in Preston in the north of England to one in 1,158 Kensington \& Chelsea, a wealthy part of London. Analysis of injuries by Road Safety Analysis Ltd (2010) found rates more than twice the national average for the group described as 'Families on lower incomes who often live in large council estates where there is little owner occupation', typically living in outer suburbs of large provincial cities. These are some of the most deprived communities in the UK, representing $6.5 \%$ of the population. However, this social gradient is not inevitable. Grayling et al. (2002) found the speed restraint measures in Hull reduced pedestrian deaths and serious injuries, particularly amongst children. Given the marked social gradient in such injuries, this measure has therefore disproportionately benefited the worse off. The Department of Transport (2003) estimated there would be 600 fewer road deaths among men aged 20-64 if everyone had the same risk of road traffic injury as men in the highest social class. These social inequalities are, at least partly, because, as discussed above, people without access to a car travel less by car and walk more than those with cars.

However, people on low incomes are also more likely to live in an inner city area where traffic is denser. Walking in this environment may be more dangerous than places where there is less traffic. Motor vehicle mortality is higher in rural than urban areas, probably exacerbated by poorer survival rates (Boland et al, 2005).

In Lothian, Scotland, road injury rates were higher in areas with more rented housing, a higher proportion of lone parent households, low car ownership and, apart from car drivers, more unemployment (Abdalla et al., 1998). Pedestrian injuries were higher in areas of higher population density, with the most residents from the lowest social class, and the most older 
people; areas with most older people also had higher rates of bus and coach injuries. Both pedestrian and car driver injury rates were higher in areas with more migrant households who had moved house in the previous 12 months.

People living in heavily trafficked inner city areas also experience more of the other adverse health effects of car use such as noise, pollution, congestion, stress and severance of communities by roads. In general, the adverse effects of car use are concentrated where car travel occurs rather than where car owners live. There is strong correlation between poverty and air (King and Stedman, 2000) and noise pollution. Less affluent districts tend to be concentrated in areas with a higher density of roads and traffic and this can lead to impaired air quality, higher noise levels and higher injury rates. For air pollution, these are often further exacerbated by other factors such as poor diet and health care access (with vulnerable groups most at risk). The very young, the old, and the frail not only are most likely to live in areas with higher air pollution but they are also the groups most at risk of the health effects of pollution.

\section{Inequalities in emissions}

Vehicles produce atmospheric emissions. These may vary for both those producing them and those affected by them. In the former case the variation is likely to be influenced by the differential use of travel modes by income while the latter is likely to be influenced by location, particularly where people live.

Brand and Boardman (2008) have estimated that those in the highest income quintile in their sample in their survey in Oxfordshire produced 3.5 times the annual emissions of the respondents in the lowest income quintile, with the differences statically significant for total travel, car, rail, taxi and air. They also found that households with access to two or more cars produced more than twice the figure for households owning one car.

Mitchell and Dorling (2003) used the results from a national study of air quality to examine the how the spatial distribution of nitrogen dioxide $\left(\mathrm{NO}_{2}\right)$ affects local communities. For car ownership, they found a linear relationship, with the most polluted areas characterised by low rates of car ownership. They examined income effects by considering levels of deprivation. They found a clear linear relationship between deprivation and pollution for the upper seven deciles of deprived areas, but also found a positive relationship for the three least deprived deciles: the poorest experience the worst air quality, but the least poor do not have the best air quality (but the very poor have much worse air quality than the least poor). It is likely that many of the very rich live in central London which has high levels of atmospheric pollution, but low car ownership because of the difficulty of finding residential parking spaces and the high level of availability of public transport and taxis.

\section{The role of the car and other modes in health inequalities}

As discussed above, the car provides the quickest and easiest way to reach various opportunities. Car ownership is strongly related to income levels, which means those with higher incomes have more access to healthy facilities than poorer people.

There is clear evidence that walking and cycling contribute to overall physical activity and so make a positive contribution to good health by reducing the risk of coronary heart disease, obesity, hypertension, depression, anxiety, and type 2 diabetes (Mackett and Brown, 2011). It might be assumed that those on lowest incomes would walk and cycle more than richer people and benefit that way, but, whilst that was true ten years ago, the growth in walking by those in the top income group and the fact that cycling generally increases with income, means that the current picture is that the greatest distance travelled by the active modes is by the top income 
group followed by the bottom group. The increase in both walking and cycling by the highest income group may be partly caused by increased awareness of the health benefits of active travel. If this is the case, it is of concern that this same trend cannot be seen amongst some of the lower income groups.

There has been an increase in the number of women who can drive whilst the number of men has levelled off since the mid-1990s, but men still travel by car more and so are able to access more opportunities to be healthy. Men and women walk about the same distance each year but men cycle much more than women, and so travel further by the active modes.

This suggests that the car is a key factor in transport inequalities. Access to a car means that there is greater opportunity to purchase healthy food and access recreation facilities for exercise, but those living in a car owning household tend to walk less than those without a car: $306 \mathrm{~km}$ a year by the former compared with $480 \mathrm{~km}$ by the latter in 2012 (Department for Transport, 2013a). This implies that those without access to a car may have the health benefits from walking more. However, Bostock (2012) argues that the lack of a car may have negative impacts on the welfare of families because those with low incomes, particularly lone mothers with young children, may be forced to walk through neglected and depressed areas because of the lack of a car or suitable public transport.

Ellaway et al. (2003) concluded that car use has positive benefits for health, since they found that, after controlling for age, sex and socio-economic circumstances people in car owning households had lower overall mortality, lower rates of long term illness, fewer symptoms, and better mental health They also found that car ownership has also been shown to perform as well if not better than current income in predicting health They set out to explore why this was the case, focusing on the role of psychosocial benefits. They found that those with access to a car gained more psychosocial benefits from their habitual mode of transport than do those who are public transport users. In particular they scored very well on items relating to control which may go some of the way to explaining the better health of car users: having a sense of efficacy and power over one's environment is related to enhanced wellbeing (Bostock and Beck 1993). Autonomy (control, flexibility, convenience) was particularly important for both sexes with protection more important for women and prestige of more significance for men.

\section{Conclusions}

There are differences in the availability of transport between the different groups in the community which, almost certainly, have implications for health. The evidence suggests that owning a car can have both positive and negative effect on health at the individual or household level. However, the evidence also shows that the car has a greater impact in terms of injuries on those of lower social status, and that those with higher incomes produce much greater levels of emissions from travelling than those with lower incomes but that those with low incomes suffer the greatest impact of emissions. This suggests that increases in income that lead to greater car ownership should, all other things being equal, lead to more casualties and more emissions which will have the greatest adverse effect on the health of those with low incomes and so contribute to more health inequalities.

Whilst the car is a major factor in the inequalities in travel that influence health, other factors also play a role: for example cultural ones, as shown in the discussion about ethnicity and geographical ones that influence differences in transport provision in urban and rural areas.

There are signs, however, that the inequalities are decreasing, mainly because levels of car ownership have levelled off for groups with high incomes whilst for others it has continued to grow. This may also mean that, while the number of low income people without a car may decrease, those without access to one will suffer even greater inequalities. 


\section{References}

Abdalla, I.M., Raeside, R., Barker, D., 1998. Linking Road Traffic Accident Statistics to Census Data in Lothian. Edinburgh: The Scottish Government, available from www.scotland.gov.uk/Publications/1998/12/d501f66f-5834-44a2-9ab9-41aa61b7b163 (accessed 24 October 2013).

Boland, M., Staines A., Fitzpatrick P., Scallan E., 2005. Urban-rural variation in mortality and hospital admission rates for unintentional injury in Ireland. Injury Prevention, 11, 38-42.

Bostock, J., Beck, D., 1993. Participating in social enquiry and action, Journal of Community and Applied Social Psychology. 3, 213-224.

Bostock, L., 2001. Pathways of disadvantage? Walking as a mode of transport among lowincome mothers, Health and Social Care in the Community, 9, 11-18.

Brand, C., Boardman, B., 2008. Taming the few- The unequal distribution of greenhouse gas emissions from personal travel in the UK, Energy Policy, 36, 224-238.

British Medical Association,1992. Cycling: Towards Health and Safety. Oxford University Press, Oxford.

Department for Environment, Food \& Rural Affairs, 2012. Diesel and Petrol Prices in Rural Areas in England (July 2011 to June 2012), available from https://www.gov.uk/government/uploads/system/uploads/attachment data/file/136598/Statistical -release-Diesel-and-Petrol-Prices-in-Rural-Areas-in-England-2011-12.pdf (accessed 24 October 2013).

Department for Environment, Food \& Rural Affairs, 2013. Statistical Digest of Rural England https://www.gov.uk/government/uploads/system/uploads/attachment data/file/245103/Statistical Digest of Rural England 2013 September Update.pdf (accessed 24 October 2013).

Department for Transport, 2003. Tackling the road safety implications of disadvantage, London.

Department for Transport, 2008. Road Casualties Great Britain, 2007. Appendix A Tables Road accidents and deprivation statistics 2007, available from http://webarchive.nationalarchives.gov.uk/20110503151558/http:/www.dft.gov.uk/adobepdf/1624 69/221412/221549/227755/rcgb2007.pdf (accessed 24 October 2013).

Department for Transport, 2013a. National Travel Survey 2012, available from https://www.gov.uk/government/publications/national-travel-survey-2012 (accessed 24 October 2013).

Department for Transport, 2013b. Transport Accessibility Statistics, available from https://www.gov.uk/government/organisations/department-for-transport/series/transportaccessibility-statistics--3 (accessed 24 October 2013).

Department for Work and Pensions, 2012. Family Resources Survey, United Kingdom, 2010/11, National Statistics, available from http://research.dwp.gov.uk/asd/frs/2010 11/frs 201011 report.pdf $\quad$ (accessed 24 October 2013).

Department for Work and Pensions, undated. Disability prevalence estimates 2007/8, Family Resources Survey (FRS), available from http://odi.dwp.gov.uk/docs/res/factsheets/disabilityprevalence.doc (accessed 24 October 2013). 
Dickinson, J.E., Kingham, S., Copsey, S, Pearlman Hougie D.J., 2003. Employer travel plans, cycling and gender: will travel plan measures improve the outlook for cycling to work in the UK? Transportation Research Part D. 8, 53-67.

Ellaway, A., Macintyre, S., Hiscock, R. Kearns, A., 2003. In the driving seat: Psychosocial benefits from private motor vehicle transport compared to public transport, Transportation Research Part F: Traffic Psychology and Behaviour. 6, 217-231.

English Federation of Disability Sport, 2013. Facts and statistics, available from http://www.efds.co.uk/resources/facts and statistics (accessed 24 October, 2013).

Farringdon J., Farrington D., 2006. Rural accessibility, social inclusion and social justice: towards conceptualisation. Journal of Transport Geography. 13, 1-12.

Foundation for People with Learning Disabilities, 2013. Statistics about people with learning disabilities, available from www.learningdisabilities.org.uk/information/learning-disabilitiesstatistics/ (accessed 24 October 2013).

Garrard, J., Rose, G., Kai Lo, S., 2008. Promoting transportation cycling for women: The role of bicycle infrastructure. Preventive Medicine. 46, 55-59.

Grayling, T., Hallam, K., Graham, D., Anderson, R., Glaister, S., 2002. Streets ahead. Safe and liveable streets for children. London: IPPR.

Hamilton, K., Jenkins, L., Hodgson, F., Turner, J., 2005. Promoting Gender Equality in Transport. Equal Opportunities Commission Working Paper. EOC, Manchester.

Hamilton, K., 2001. Gender and Transport in Developed Countries, Background paper for the Expert Workshop on 'Gender Perspectives for Earth Summit 2002: Energy, Transport, Information for Decision Making', Berlin.

Horten, T., Reed, H, 2010. Where the money goes: How we benefit from public services, Trades Union Congress, available from http://www.tuc.org.uk/sites/default/files/extras/wherethemoneygoes.pdf $\quad$ (accessed 10 June 2014).

Mackett, R. L., 2014. The impacts of concessionary travel passes for older and disabled people - a review of the evidence, Report produced as a contribution to the work of the CILT Concessionary Travel Group and the CILT Accessibility and Inclusion Forum, Chartered Institute of Logistics and Transport, available from www.bit.ly/concessionary (accessed 10 June 2014).

Mackett, R. L., Brown, B., 2011, Transport, Physical Activity and Health: Present knowledge and the way ahead, Scanning Study commissioned by the Department for Transport, London, Great Britain, carried out through the UK Transport Research Centre (UKTRC), available from https://www.ucl.ac.uk/news/pdf/transportactivityhealth.pdf (accessed 10 June 2014).

Mitchell, G., Dorling, D (2003) An environmental justice analysis of British air quality, Environment and Planning A, 909-929. http://www.sasi.group.shef.ac.uk/publications/2003/mitchell and dorling air quality.pdf

NHS Choices, 2013. Hearing impairment, available from http://www.nhs.uk/conditions/hearingimpairment/pages/introduction.aspx (accessed 24 October 2013).

Office for Disability Issues, 2011. Life Opportunities Survey: Wave one results, 2009/11, available

from

https://www.gov.uk/government/uploads/system/uploads/attachment data/file/180891/los wave one 200911.pdf (accessed 24 October 2013). 
Office for National Statistics, 2012a. Family Spending, available from http://www.ons.gov.uk/ons/rel/family-spending/family-spending/family-spending-2012edition/index.html (accessed 24 October 2013).

Office for National Statistics, 2012b. National Population Projections, 2010-based reference volume: Series PP2, available from http://www.ons.gov.uk/ons/rel/npp/national-populationprojections/2010-based-reference-volume--series-pp2/index.html (accessed 24 October 2013).

Oja, P., Vuori, I., Paronen, O., 1998. Daily walking and cycling to work: their utility as healthenhancing physical activity. Patient Education and Counselling. 33, 87-94.

Pazy, A., Salomon, I., Pintzov, T., 1996. The impacts of women's careers on their commuting behavior: A case study of Israeli computer professionals. Transportation Research A. 30, 26986.

Reid-Howie Associates, 2000. Women and Transport: Moving Forward. Report for the Scottish Executive Central Research Unit. The Stationery Office, Edinburgh.

RNIB, 2013, Key information and statistics, available from http://www.rnib.org.uk/aboutus/research/statistics/Pages/statistics.aspx (accessed 24 October 2013).

Road Safety Analysis Ltd., 2010. Child Casualties Report 2010. A study into resident risk of children on roads in Great Britain 2004-08.,: RSA Ltd, Moreton-in-Marsh, Gloucestershire, available from http://www.roadsafetyanalysis.org/wp-content/uploads/sites/13/2010/08/ChildCasualty-Report-2010.pdf (accessed 24 October 2013)

Rosenbloom, S., Burns, E., 1994. Why working women drive alone: the implications for travel reduction programs. Paper prepared for the 1994 Annual Meeting of the Transportation Research Board.

Spain, D., 1996. Run don't walk: how transportation complicates women's balancing act. US Department of Transportation. Federal Highway Administration, Washington D.C.

Vaganay, M., Woodside, A.R., Harvey, H., 2003. Child pedestrian traffic exposure and road behaviour. Proceedings of the European Transport Conference, available from http://abstracts.aetransport.org/paper/index/id/1757/confid/9 (accessed 24 October 2013). 